\title{
FAKTOR-FAKTOR YANG MEMPENGARUHI KEJADIAN PENYAKIT JANTUNG KORONER DI RSUD RANTAU PRAPAT TAHUN 2020
}

\author{
Dian Christy Rahayu ${ }^{1}$, Lukman Hakim ${ }^{2}$, Karnirius Harefa ${ }^{3}$ \\ Pascasarjana Ilmu Kesehatan Masyarakat ${ }^{1}$, Dosen Departemen Kesehatan Masyarakat ${ }^{2,3}$ \\ Magister Ilmu Kesehatan Masyarakat, Universitas Sari Mutiara Indonesia, Medan \\ Dainchristy@gmail.com¹, @hakimlukman@gmail.com²
}

\begin{abstract}
Coronary heart disease is a disorder in one or more coronary blood vessels where there is thickening in the walls of blood vessels accompanied by plaque that interferes with blood flow to the heart muscle which consequently can interfere with heart function. The purpose of this study was to analyze the factors related to the incidence of coronary heart disease at the Rantauparapat Hospital in 2020. This type of research was an analytic study with a case control approach. With a total population of 3278 and the number of samples is 43 cases and 43 controls. The result of this research is that there is a relationship between family history and the incidence of coronary heart disease with $p$ value 0.012 . There is no relationship between age and the incidence of coronary heart disease, namely $p$ value 0.205. There is a relationship between gender and the incidence of coronary heart disease, namely $p$ value 0.021. There is a relationship between hypertension and the incidence of coronary heart disease, namely $p$ value 0.003 . There is no relationship between obesity and the incidence of coronary heart disease, namely $p$ value 0.257. There is a relationship between smoking and the incidence of coronary heart disease that is $p$ value 0.030 . There is a relationship between physical activity and the incidence of coronary heart disease, namely $p$ value 0.022. The most dominant factor associated with the incidence of Coronary Heart Disease is the Hypertension variable. It is recommended to the public to always do a medical check-up to find out the health condition of a disease early.
\end{abstract}

Keywords $\quad$ : Factors, Coronary Heart Disease

\begin{abstract}
ABSTRAK
Penyakit Jantung koroner merupakan kelainan pada satu atau lebih pembuluh darah koroner dimana terdapat penebalan dalam dinding pembuluh darah disertai adanya plak yang mengganggu aliran darah ke otot jantung yang akibatnya dapat mengganggu fungsi jantung. Tujuan penelitian ini untuk menganalisis faktor-faktor yang berhubungan antara kejadian penyakit jantung koroner di RSUD Rantauparapat tahun 2020. Jenis penelitian ini yaitu penelitian analitik dengan pendekatan case control. Dengan jumlah populasi yaitu sebanyak 3278 dan jumlah sampel yaitu 43 case dan 43 control. Hasil penelitian yaitu terdapat hubungan riwayat keluarga dengan kejadian Penyakit Jantung Koroner yaitu $p$ value 0,012 . Tidak Terdapat hubungan antara Umur dengan kejadian Penyakit Jantung Koroner yaitu $p$ value 0,205 . Terdapat hubungan antara Jenis Kelamin dengan kejadian Penyakit Jantung Koroner yaitu $p$ value 0,021 . Terdapat hubungan antara Hipertensi dengan kejadian Penyakit Jantung Koroner yaitu $p$ value 0,003 . Tidak Terdapat hubungan antara Obesitas dengan kejadian Penyakit Jantung Koroner yaitu $p$ value 0,257. Terdapat hubungan antara Merokok dengan kejadian Penyakit Jantung Koroner yaitu $p$ value 0,030 . Terdapat hubungan antara Aktivitas Fisik dengan kejadian Penyakit Jantung Koroner yaitu $p$ value 0,022. Faktor yang paling dominan berhubungan dengan kejadian Penyakit Jantung Koroner yaitu variabel Hipertensi. Disarankan kepada masyarakat agar selalu melakukan medical check up untuk mengetahui kondisi kesehatan suatu penyakit secara dini.
\end{abstract}

Kata Kunci : Faktor, Penyakit Jantung Koroner 


\section{PENDAHULUAN}

Penyakit Jantung koroner adalah penyakit pembuluh darah yang menyuplai makanan dan oksigen untuk otot jantung mengalami sumbatan (Kurniadi, 2013). Penyakit Jantung koroner merupakan kelainan pada satu atau lebih pembuluh darah koroner dimana terdapat penebalan dalam dinding pembuluh darah disertai adanya plak yang mengganggu aliran darah ke otot jantung yang akibatnya dapat mengganggu fungsi jantung (AHA, 2015). Pada umumnya faktor risiko PJK dipengaruhi oleh merokok, obesitas, kurang aktivitas fisik dan tekanan darah tinggi atau hipertensi (WHO, 2011).

Riskesdas 2018 menunjukkan prevalensi penyakit jantung berdasarkan diagnose dokter di Indonesia sebesar 1,5\% dengan peringkat prevalensi tertinggi yaitu provinsi Kalimantan Utara sebanyak 2,2\%, DIY sebanyak 25 dan Gorontalo sebanyak 2\%. Selain ketiga provinsi tersebut, terdapat pula 8 provinsi lainnya dengan prevalensi yang lebih tinggi jika dibandingkan dengan prevalensi nasional, yaitu Aceh, Sumatera Barat, DKI Jakarta, Jawa Barat, Jawa Tengah, Kalimantan Timur, Sulawesi Utara dan Sulawesi Tengah (Riskesdes, 2018).

Berdasarkan jenis kelamin, prevalensi PJK di Indonesia lebih tinggi pada perempuan $(1,6 \%)$ dibanding laki-laki $(1,3 \%)$. Sedangkan jika dilihat dari sisi pekerjaan, ironisnya penderita PJK tertinggi terdapat pada aparat pemerintah yaitu PNS/ TNI/ Polri/ BUMN/ BUMD dengan prevalensi $2,7 \%$. Begitu juga jika dilihat dari tempat tinggal, penduduk perkotaan lebih banyak menderita PJK dengan prevalensi $1,6 \%$ disbanding penduduk perdesaan yang hanya $1,3 \%$. Data BPJS menunjukkan adanya peningkatan biaya kesehatan untuk PJK dari tahun ke tahun. Pada tahun 2014 PJK menghabiskan data BPJS sebanyak 4,4 Triliun Rupah, kemudian meningkat menjadi 7,4 Triliun Rupiah pada tahun 2016 dan masih terus meningkat pada tahun 2018 sebesar 9,3 Triliun Rupiah. Hal ini menunjukkan besarnya beban Negara terhadap penanggulangan PJK, yang seharusnya dapat dikendalikan dengan mengendalikan factor resiko.

Dari studi pendahuluan yang penulis lakukan di RSUD Rantauprapat didapatkan data penderita dengan diagnosis penyakit jantung koroner pada tahun 2018 yaitu sebanyak 2976 penderita. Pada tahun 2019 yaitu sebanyak 3271 penderita. Data tersebut didapatkan dari penderita jantung yang berobat ke RSUD Rantauparapat (RSUD Rantauparapat 2020).

Angka kejadian jantung koroner yang terjadi di RSUD Rantau Prapapat yang selalu mengalami peningkatan, maka peneliti ingin mengetahui apa saja faktor faktor yang mempengaruhi kejadian penyakit koroner di RSUD Rantauparapat tahun 2020. Dan penelian ini bertujuan untuk menganalisis faktor-faktor yang berhubungan antara kejadian penyakit jantung koroner di RSUD Rantauparapat tahun 2020.

\section{METODE}

Jenis dan rancangan pada penelitian ini adalah penelitian analitik dengan metode survei dengan cara penyebaran kuesioner dan wawancara kepada penderita penyakit jantung koroner secara langsung dengan pendekatan Case Control. Populasi dalam penelitian ini adalah seluruh masyarakat yang berobat di Poliklinik Jantung RSUD Rantauprapat untuk tahun 2018 yaitu sebanyak 3278 orang dan untuk tahun 2019 yaitu sebanyak 3501 orang dengan jumlah rata-rata perbulan yaitu 300 orang. Besar sampel secara keseluruhan pada penelitian ini adalah 86 (kasus dan control), dengan perbandingan antara kasus dan control adalah 1:1 yaitu jumlah kasus 43 dan jumlah control 43. Teknik pengambilan sampel dalam penelitian ini adalah dengan menggunakan Nonprobability sampling yaitu Consecutive sampling 
HASIL

\section{Hubungan Antara Riwayat Keluarga Terhadap Kejadian Penyakit Jantung Koroner}

Tabel 1. Tabulasi Silang Hubungan Antara Riwayat Keluarga Terhadap Kejadian Penyakit Jantung Koroner di RSUD Rantauprapat Kabupaten Labuhanbatu Tahun 2020.

\begin{tabular}{|c|c|c|c|c|c|c|c|}
\hline \multirow{3}{*}{$\begin{array}{l}\text { Riwayat } \\
\text { Keluarga }\end{array}$} & \multicolumn{4}{|c|}{ Kejadian PJK } & \multirow{3}{*}{ OR } & \multirow{3}{*}{$95 \% \mathrm{CI}$} & \multirow{3}{*}{$\begin{array}{l}\text { Nilai } p \\
\text { value }\end{array}$} \\
\hline & \multicolumn{2}{|c|}{ Kasus } & \multicolumn{2}{|c|}{ Kontrol } & & & \\
\hline & $\mathbf{N}$ & $\%$ & $\mathbf{N}$ & $\%$ & & & \\
\hline $\begin{array}{l}\text { Ada } \\
\text { Riwayat }\end{array}$ & 23 & 53,4 & 17 & 39,5 & 3,19 & $1,36-7,50$ & 0,012 \\
\hline $\begin{array}{l}\text { Tidak Ada } \\
\text { Riwayat }\end{array}$ & 20 & 46,5 & 26 & 60,4 & & & \\
\hline Jumlah & 43 & 100 & 43 & 100 & & & \\
\hline
\end{tabular}

Pada tabel 1 dapat dijelaskan hasil penelitian bahwa responden yang memiliki riwayat dari keluarga pada kelompok kasus lebih banyak $(53,4 \%)$ dibandingkan dengan pada kelompok control (39,5\%). Berdasarkan hasil uji chi square di dapatkan hasil ada pengaruh riwayat keluarga terhadap kejadian PJK pada masyarakat yang berobat di RSUD Rantauprapat dengan nilai $p$ value $0,012(0,012<0,05)$ dan nilai OR sebesar 3,19 yang artinya responden yang memiliki riwayat dari keluarga memiliki 3,19 kali untuk mengalami kejadian PJK dibandingkan dengan yang tidak memiliki riwayat dari keluarga.

\section{Hubungan Antara Umur Terhadap Kejadian Penyakit Jantung Koroner}

Tabel 2. Tabulasi Silang Hubungan Antara Umur Terhadap Kejadian Penyakit Jantung Koroner di RSUD Rantauprapat Kabupaten Labuhanbatu Tahun 2020.

\begin{tabular}{|c|c|c|c|c|c|c|c|}
\hline \multirow{3}{*}{ Umur } & \multicolumn{4}{|c|}{ Kejadian PJK } & \multirow{3}{*}{ OR } & \multirow{3}{*}{$95 \% \mathrm{CI}$} & \multirow{3}{*}{$\begin{array}{c}\text { Nilai } p \\
\text { value }\end{array}$} \\
\hline & \multicolumn{2}{|c|}{ Kasus } & \multicolumn{2}{|c|}{ Kontrol } & & & \\
\hline & $\mathbf{N}$ & $\%$ & $\mathbf{N}$ & $\%$ & & & \\
\hline$<40$ Tahun & 9 & 20,9 & 21 & 48,8 & 0,182 & $0,02-1,62$ & 0,203 \\
\hline$>40$ Tahun & 34 & 79,0 & 22 & 51,1 & & & \\
\hline Jumlah & 43 & 100,0 & 43 & 100,0 & & & \\
\hline
\end{tabular}

Pada tabel 2 dapat dijelaskan hasil penelitian bahwa responden dengan umur lebih dari atau sama dengan 40 tahun pada kelompok kasus lebih banyak $(79,0 \%)$ dibandingkan pada kelompok control $(51,1 \%)$. Berdasarkan hasil uji chi square di dapatkan hasil tidak ada pengaruh umur terhadap kejadian PJK pada masyarakat yang berobat ke RSUD Rantauprapat dengan nilai $p$ value $0,203(0,203>0,05)$.

Hubungan Antara Jenis Kelamin Terhadap Kejadian Penyakit Jantung Koroner
Pada tabel 3 dapat dijelaskan hasil peneitian Bahwa responden dengan jenis kelamin laki-laki pada kelompok kasus lebih banyak $(60,4 \%)$ dibandingkan dengan kelompok kontrol $(51,1 \%)$. Berdasarkan hasil uji chi square di dapatkan hasil ada pengaruh jenis kelamin terhadap kejadian PJK pada masyarakat yang berobat di RSUD Rantauprapat dengan nilai $p$ value $0,021(0,021<0,05)$ dan nilai OR sebesar 2,97 yang artinya responden dengan jenis kelamin pria memiliki 2,97 kali untuk mengalami kejadian PJK dibandingkan dengan jenis kelamin wanita. 
Tabel 3. Tabulasi Silang Hubungan Antara Jenis Kelamin Terhadap Kejadian Penyakit Jantung Koroner di RSUD Rantauprapat Kabupaten Labuhanbatu Tahun 2020.

\begin{tabular}{|c|c|c|c|c|c|c|c|}
\hline \multirow{3}{*}{ Jenis Kelamin } & \multicolumn{4}{|c|}{ Kejadian PJK } & \multirow{3}{*}{ OR } & \multirow{3}{*}{$95 \% \mathrm{CI}$} & \multirow{3}{*}{$\begin{array}{c}\text { Nilai } p \\
\text { value }\end{array}$} \\
\hline & \multicolumn{2}{|c|}{ Kasus } & \multicolumn{2}{|c|}{ Kontrol } & & & \\
\hline & $\mathbf{N}$ & $\%$ & $\mathbf{N}$ & $\%$ & & & \\
\hline Laki-Laki & 26 & 60,4 & 22 & 51,1 & 2,97 & $1,26-7,00$ & 0,021 \\
\hline Perempuan & 17 & 39,5 & 21 & 48,8 & & & \\
\hline Jumlah & 43 & 100,0 & 43 & 100,0 & & & \\
\hline
\end{tabular}

\section{Hubungan Antara Hipertensi Terhadap Kejadian Penyakit Jantung Koroner}

Tabel 4. Tabulasi Silang Hubungan Antara Hipertensi Terhadap Kejadian Penyakit Jantung Koroner di RSUD Rantauprapat Kabupaten Labuhanbatu Tahun 2020.

\begin{tabular}{|c|c|c|c|c|c|c|c|}
\hline \multirow{3}{*}{ Hipertensi } & \multicolumn{4}{|c|}{ Kejadian PJK } & \multirow{3}{*}{ OR } & \multirow{3}{*}{$95 \% \mathrm{CI}$} & \multirow{3}{*}{$\begin{array}{c}\text { Nilai } p \\
\text { value }\end{array}$} \\
\hline & \multicolumn{2}{|c|}{ Kasus } & \multicolumn{2}{|c|}{ Kontrol } & & & \\
\hline & $\mathbf{N}$ & $\%$ & $\mathbf{N}$ & $\%$ & & & \\
\hline Hipertensi & 37 & 86,0 & 28 & 65,1 & & & \\
\hline $\begin{array}{l}\text { Tidak } \\
\text { Hipertensi }\end{array}$ & 6 & 13,9 & 15 & 34,8 & 4,13 & $\begin{array}{l}1,69 \\
10,11\end{array}$ & 0,003 \\
\hline Jumlah & 43 & 100,0 & 43 & 100,0 & & & \\
\hline
\end{tabular}

Pada tabel 4 dapat dijelaskan hasil penelitian bahwa responden dengan hipertensi pada kelompok kasus lebih banyak $(86,0 \%)$ dibandingkan pada kelompok control $(65,1 \%)$. Berdasarkan hasil uji chi square di dapatkan hasil ada pengaruh hipertensi terhadap kejadian PJK pada masyarakat yang berobat ke RSUD Rantauprapat dengan nilai $p$ value 0,003 $(0,003<0,05)$ dan nilai OR sebesar 4,13 yang artinya responden dengan hipertensi memiliki 4,13 kali untuk mengalami kejadian PJK dibandingkan dengan yang tidak hipertensi.

\section{Hubungan Antara Obesitas Terhadap Kejadian Penyakit Jantung Koroner}

Pada tabel 5 dapat dijelaskan hasil penelitian bahwa responden yang tidak obesitas pada kelompok kasus lebih sedikit $(55,8 \%)$ dibandingkan pada kelompok kontrol $(69,7 \%)$. Hal ini terlihat pada tabel 4.20 diatas. Berdasarkan hasil uji chi square di dapatkan hasil tidak ada pengaruh obesitas terhadap kejadian PJK pada masyarakat yang berobat di RSUD Rantauprapat dengan nilai $p$ value 0,257 $(0,257>0,05)$.

Tabel 5. Tabulasi Silang Hubungan Antara Obesitas Terhadap Kejadian Penyakit Jantung Koroner di RSUD Rantauprapat Kabupaten Labuhanbatu Tahun 2020.

\begin{tabular}{|c|c|c|c|c|c|c|c|}
\hline \multirow{3}{*}{ Obesitas } & \multicolumn{4}{|c|}{ Kejadian PJK } & \multirow{3}{*}{ OR } & \multirow{3}{*}{$95 \% \mathrm{CI}$} & \multirow{3}{*}{$\begin{array}{c}\text { Nilai } p \\
\text { value }\end{array}$} \\
\hline & \multicolumn{2}{|c|}{ Kasus } & \multicolumn{2}{|c|}{ Kontrol } & & & \\
\hline & $\mathbf{N}$ & $\%$ & $\mathbf{N}$ & $\%$ & & & \\
\hline Obesitas & 19 & 44,1 & 13 & 30,2 & & & \\
\hline Tidak Obesitas & 24 & 55,8 & 30 & 69,7 & 1,86 & $0,75-4,60$ & 0,257 \\
\hline Jumlah & 43 & 100,0 & 43 & 100,0 & & & \\
\hline
\end{tabular}




\section{Hubungan Antara Merokok Terhadap Kejadian Penyakit Jantung Koroner}

Tabel 6. Tabulasi Silang Hubungan Antara Merokok Terhadap Kejadian Penyakit Jantung Koroner di RSUD Rantauprapat Kabupaten Labuhanbatu Tahun 2020.

\begin{tabular}{|c|c|c|c|c|c|c|c|}
\hline \multirow{3}{*}{ Merokok } & \multicolumn{4}{|c|}{ Kejadian PJK } & \multirow{3}{*}{ OR } & \multirow{3}{*}{$95 \% \mathrm{CI}$} & \multirow{3}{*}{$\begin{array}{c}\text { Nilai } p \\
\text { value }\end{array}$} \\
\hline & \multicolumn{2}{|c|}{ Kasus } & \multicolumn{2}{|c|}{ Kontrol } & & & \\
\hline & $\mathbf{N}$ & $\%$ & $\mathbf{N}$ & $\%$ & & & \\
\hline Merokok & 16 & 37,2 & 24 & 55,8 & & & \\
\hline Tidak Merokok & 27 & 62,7 & 19 & 44,1 & 2,91 & $1,19-7,10$ & 0,030 \\
\hline Jumlah & 43 & 100,0 & 43 & $\mathbf{1 0 0 , 0}$ & & & \\
\hline
\end{tabular}

Pada tabel 6 dapat dijelaskan hasil penelitian bahwa responden dengan kebiasaan merokok pada kelompok kasus lebih sedikit $(37,2 \%)$ dibandingkan pada kelompok kontrol (55,8\%). Berdasarkan hasil uji chi square di dapatkan hasil ada pengaruh merokok terhadap kejadian PJK pada masyarakat yang berobat di RSUD
Rantauprapat dengan nilai $p$ value 0,030 $(0,030<0,05)$ dan nilai OR sebesar 2,91 yang artinya responden dengan kebiasaan merokok emiliki 2,91 kali untuk mengalami kejadian PJK dibandingkan dengan yang tidak memiliki kebiasaan merokok.

\section{Hubungan Antara Aktivitas Fisik Terhadap Kejadian Penyakit Jantung Koroner}

Tabel 7. Tabulasi Silang Hubungan Antara Aktivitas Fisik Terhadap Kejadian Penyakit Jantung Koroner di RSUD Rantauprapat Kabupaten Labuhanbatu Tahun 2020.

\begin{tabular}{lccccccc}
\hline \multirow{2}{*}{ Aktivitas Fisik } & \multicolumn{9}{c}{ Kejadian PJK } & OR & 95\% CI & $\begin{array}{c}\text { Nilai } \boldsymbol{p} \\
\text { value }\end{array}$ \\
\cline { 2 - 5 } & & $\mathbf{N}$ & $\mathbf{\%}$ & $\mathbf{N}$ & $\mathbf{\%}$ & & \\
\hline Kurang & 38 & 88,3 & 25 & 58,1 & 2,91 & $1,24-6,80$ & 0,22 \\
Cukup & 5 & 11,6 & 18 & 41,8 & & & \\
\hline
\end{tabular}

Pada tabel 7 dapat dijelaskan hasil penelitian bahwa responden dengan aktivitas fisik kurang pada kelompok kasus lebih banyak $(88,3 \%)$ dibandingkan pada kelompok kontrol $(58,1 \%)$. Berdasarkan hasil uji chi square di dapatkan hasil ada pengaruh aktivitas fisik terhadap kejadian PJK pada masyarakat yang berobat di RSUD Rantauprapat dengan nilai $p$ value 0,022 $(0,022<0,05)$ dan nilai OR sebesar 2,91 yang artinya responden dengan aktivitas fisik kurang memiliki 2,91 kali untuk mengalami kejadian PJK dibandingkan dengan aktivitas fisik cukup.

\section{PEMBAHASAN}

Sesuai teori menyatakan bahwa penyakit jantung koroner cenderung terjadi pada subyek yang orang tua nya sudah menderita penyakit jantung koroner sejak usia muda yaitu pada usia 55 tahun untuk anggota pria (ayah atau saudara laki-laki) dan usia 65 untuk anggota wanita (ibu atau saudara perempuan). Adanya riwayat keluarga dekat yang terkena penyakit jantung dan pembuluh darah meningkatkan risiko penyakit jantung dan pembuluh darah dua kali lebih besar dibandingkan dengan yang tidak memiliki riwayat dari keluarga (Notoatmodjo, 2011).

Berdasarkan hasil pengamatan dilapangan pada penderita PJK terdapat 
23 responden memang memiliki riwayat dari keluarga dan 17 responden memilki riwayat dari keluarga namun tidak menderita PJK. Pada saat dilakukan pengamatan kepada responden yang tidak menderita PJK, mereka bisa mengontrol gaya hidup sedari dini. Sudah banyak masyarakat yang sadar bahwa ada nya riwayat PJK dari orang tua sehingga mereka melakukan gaya hidup yang lebih baik.Berdasarkan hasil pengamatan dilapangan, memang didapatkan bahwa responden berjenis kelamin wanita lebih banyak dibandingkan dengan responden dengan jenis kelamin laki-laki.

Namun hal ini karena berkaitan juga dengan faktor usia dimana selama pengamatan dilakukan memang responden dengan usia diatas 40 tahun lebih banyak. Dimana hormone estrogen pada wanita menopause menjadi berkurang dan menyebabkan tingkat resiko terjadinya PJK menjadi sama dengan laki-laki.

Penelitian ini sesuai dengan teori yang ada bahwa orang yang mempunyai darah yang tinggi berisiko untuk mengalami penyakit jantung, ginjal, bahkan stroke. Tekanan darah yang tinggi membuat jantung bekerja dengan berat, sehingga lama kelamaan jantung juga akan kecapaian dan sakit. Bahkan apabila ada sumbatan di pembuluh darah koroner jantung maupun pembuluh darah yang lain, tekanan darah yang tinggi akan membuat risiko pecahnya pembuluh darah. Hipertensi merupakan penyebab tersering penyakit jantung koroner dan stroke, serta faktor utama dalam gagal jantung kongestif (Kurniadi, 2013).

Penelitian melaporkan kaitan erat antara obesitas sentral atau obesitas abdominal (perut) dengan penyakit jantung koroner. Jaringan lemak abdominal merupakan predictor terjadinya penyakit jantung koroner dan kematian. Framingham study mengungkapkan bahwa insiden PJK meningkat dengan meningkatnya berat badan baik pada pria maupun wanita. Obesitas juga merupakan faktor resiko bagi hipertensi, diabetes, hiperlipidemia, tetapi dapat dikurang dengan aktifitas fisik/olahraga secara rutin dan diet. Sehingga pengaruh obesitas pada PJK tidak selalu bisa berdiri sendiri, tetapi biasanya diperburuk dengan faktor resiko yang lain (Notoatmodjo,2011).

Berdasarkan hasil penelitian yang dilakukan terhadap penderita PJK dan bukan PJK didapatkan hasil bahwa penderita PJK yang tidak mempunyai obesitas lebih banyak dibandingkan yang mempunyai obesitas. Dari responden yang tidak mengalami obesitas namun bisa menderita PJK karena adanya faktor lain yang menjadi pemicu terjadinya PJK yaitu adanya riwayat hipertensi dan juga riwayat PJK dari keluarga. Dan juga dari responden mengaku bahwa perlah?an sudah melakukan pola hidup sehat untuk menurunkan berat badan.

\section{KESIMPULAN}

Bedasarkan hasil penelitian tersebut dapat disimpulkan bahwa terdapat hubungan antara Riwayat Keluarga, Jenis Kelamin, Hipertensi, Merokok dan Aktivitas Fisik dengan kejadian Penyakit Jantung Koroner di RSUD Rantauparapat tahun 2020 dan tidak terdapat hubungan antara umur dan obesitas dengan kejadian Penyakit Jantung Koroner di RSUD Rantauprapat tahun 2020. Variabel Hipertensi merupakan faktor yang paling dominan berhubungan dengan kejadian Penyakit Jantung Koroner.

\section{UCAPAN TERIMAKASIH}

Peneliti mengucapkan terimakasih kepada segenap keluarga besar RSUD Rantauprapat yang sudah bersedia menjadi responden dalam penelitian ini dan telah membantu dalam proses penelitian ini.

\section{DAFTAR PUSTAKA}

Arikunto, Suharsimi. 2013. Prosedur Penelitian : Suatu Pendekatan Praktik. Jakarta: Rineka Cipta 
Buku Pintar POSBINDU PTM. 2016. Penyakit Tidak Menular Dan Faktor Risiko: Kemekes RI.

Diastutik, Desi. 2017. Proporsi Karakteristik Penyakit Jantung Koroner Pada Perokok Aktif Berdasarkan Karakteristik Merokok. Surabaya: Vol 4, No 3.

Hidayat, Aziz Alimul. 2012. Riset Keperawatan dan Teknik Penulisan Ilmiah. Jakarta: Salemba Medika

Irianto, Koes. 2014. Epidemiologi Penyakit Menular dan Tidak Menular Panduan Klinis. Bandung: Alfabeta

Iskandar, Abdul Hadi, Alfridsyah. 2017. Faktor Risiko Terjadinya Penyakit Jantung Koroner Pada Pasien Rumah Sakit Umum Meuraxa Banda Aceh. Aceh : Vol 2, No 1

Karo-Karo, Santoso. 2016. Cegah dan Atasi Penyakit Jantung dan Pembuluh Darah:karna hidup hanya sekali. Jakarta: Praninta Aksara

Kurniadi, Helmanu. 2013. Stop! Gejala Penyakit Jantung Koroner. Yogyakarta: Familia.

Ma'rufi, R, Rosita, L. 2014. Hubungan Dislipidemia dan Kejadian Jantung Koroner. Yogyakarta : Vol 6, No 1

Naga, Sholeh S. 2012. Buku Panduan Lengkap Ilmu Penyakit Dalam. Yogyakarta: Diva Press

Notoatmodjo, Soekidjo. 2010. Metodologi Penelitian Kesehatan. Jakarta : Rineka Cipta

Notoatmodjo, Soekidjo. 2011. Kesehatan Masyarakat: Ilmu dan Seni. Jakarta : Rineka Cipta

Nurainin, Binti. 2015. Risk Factors of Hypertension. Lampung : Vol 4. No 5

Nursalam. 2013. Metode Penelitian. Jakarta : Salemba Medika : Universitas Indonesia
Oemiati, Ratih, Rustika. 2015. Faktor Risiko Penyakit Jantung Koroner Pada Perempuan. Jakarta : Vol 18. No 1

Proverawati, Atikah, Emi Sulistyawati. 2010. Menopause dan Sindrom Premenopause. Yogyakarta: Nuha Medika

Saryono dan Dwi Anggraeni, Mekar. 2013. Metodologi Penelitian Kualitatif dan Kuantitatif Dalam Bidang Kesehatan. Yogyakarja: Nuha Medika

Sugiyono.2008. Metode Penelitian Pendidikan penelitian kuantitatif, kualitatif, $R \& D$. Bandung: Alfabeta

Utaminingsih, Wahyu Rahayu. 2015. Mengenal \& Mencegah Penyakit Diabetes, Hipertensi, Jantung dan Stroke Untuk Hidup Lebih Berkualitas. Yogyakarta: Media Ilmu

Zahrawardani, Diana, Kuntio Sri Herlambang, Hema Dewi Anggraheny. 2013. Analisis Faktor Risiko Kejadian Penyakit Jantung Koroner di RSUP Dr Kariadi Semarang. Semarang : vol 2 